\title{
EDYTA STEIN W PAMIĘCI WROCŁAWIA
}

Większość autorów przedstawiających biografię Edyty Stein zwraca uwagę na wyjątkowość dnia, w którym się urodziła. Przyszła na świat w żydowskie święto Jom Kippur, Dzień Pojednania, w którym dopełnia się dziesięciodniowy rytuał pokuty, a Żyd staje się aniołem, co podkreśla biel przywdziewanej wówczas szaty. Właśnie to święto „zawisło jak przepowiednia nad jej życiem i umieraniem”, niczym znak powołania i ofiary, poprzez którą połączyły się w świadectwie Edyty Stein judaizm i chrześcijaństwoํ. Czy religijny sens, który objawia się w mitologizacji czasu, w znaczeniu, jakie przypisuje się dacie urodzin wrocławskiej świętej, ogarnia również przestrzeń? Miejsce, w którym przyszła na świat, spędziła dzieciństwo, dorastała? Czy podążanie śladem biograficznej opowieści i lektura wspomnień z czasów młodości pozwala zrozumieć jej drogę do świętości, odczytać sens duchowej przemiany? Zwykle taka właśnie nadzieja, poza nieco fetyszystyczną ciekawością, towarzyszy dokumentowaniu śladów obecności bądź muzealizacyjnym zabiegom, związanym z postaciami świętych.

${ }^{1}$ A. Paliszek, Judaistyczne korzenie duchowości Edyty Stein, „Kwartalnik TES” 2005, 03/05(12), s. 5. Autor zwraca uwagę nie tylko na przebłagalny charakter Jom Kippur, ale na też na jego związek z ofiarą, której spełnieniem jest śmierć s. Teresy Benedykty od Krzyża w Auschwitz. Pisze: „Edyta przywiązywała już od dzieciństwa dużą wagę do dnia swych narodzin. W miarę upływu czasu po przejściu na katolicyzm i coraz głębszych doświadczeniach dźwigania krzyża, jakim był antysemityzm narodu niemieckiego, coraz wyraźniej odczuwała prorocze znaczenie Dnia Pojednania w jej życiu i wynikającego z niego powołania do ofiary i cierpienia". 
Zadając te pytania, nie stawiam jednak przed sobą zadania rozpoznania genius loci $\mathrm{w}$ tym, co tworzy klimat $\mathrm{i}$ atmosferę Wrocławia przełomu XIX i XX wieku². Był to okres rozkwitu i otwartości, które miasto w dużej mierze zawdzięcza ożywczemu duchowi reformowanego, nowoczesnego ${ }^{3}$ judaizmu, i w tej atmosferze funkcjonował także dom rodzinny Steinów. Nie chodzi zatem o to, jak ówczesny Wrocław wpływał na wyobraźnię, uczucia, sposób myślenia Edyty Stein, choć z pewnością wrocławskie lata stanowią ważną część biografii przyszłej patronki Europy. Warto przy okazji zauważyć, że współczesne hagiograficzne opowieści, przedstawiając życie świętych jako świadectwo ich świętości, nie zacierają już unikalnego i jednostkowego charakteru egzystencji, jak czyniła to niegdyś słynna Złota legenda Jakuba z Voraginy. Przeciwnie - podkreślają zakorzenienie drogi ku świętości w świeckim doświadczeniu, pobudzają wiarę, wskazując procesualny wymiar przemiany, jaka staje się udziałem świętych, a możliwie pełne ujęcie ich biografii służy za przykład do naśladowania. Taka perspektywa z pewnością uzasadnia zainteresowanie wrocławskim okresem życia Edyty Stein.

Problematyka, którą chcę podjąć, dotyczy natomiast współczesnej tożsamości miasta i miejsca, jakie w jej kształtowaniu zajmują duchowi przewodnicy. Zależy mi zatem na próbie odpowiedzi na pytanie, czy narodziny i wrocławskie lata Edyty Stein przekształcają dziś miejską przestrzeń, czyniąc zeń część symbolicznego krajobrazu Wrocławia? W odczarowanym świecie, w którym patronat traktowany jest w kategoriach kulturowego dziedzictwa, a przedstawienia świętych funkcjonują $\mathrm{w}$ ramach kampanii promujących miasta, pytanie to wydaje się prowadzić jedynie do opisu strategii wizerunkowych i oficjalnych praktyk upamiętniania. Na proces zastępowania chrześcijańskich ram europejskiej pamięci przez rozmaite formy pamięci obywatelskiej i ich społeczny wymiar wskazywał już Maurice Halbwachs. Wydaje się jednak, że istnieją powody, by na rolę, jaką postać Edyty Stein odgrywa $\mathrm{w}$ tworzeniu tożsamości Wrocławia, spojrzeć z perspektywy, która nie zakłada traktowania tych ram jako wzajemnie się wykluczających. A co za tym idzie - przyjąć rozumienie pamięci jako procesu czy praktyki, w których

${ }^{2}$ Z tej perspektywy życiu Edyty Stein przygląda się Agnieszka Rybińska np. w tekście: Wielokulturowe elementy tożsamości Edith Stein, „Kwartalnik TES” 2004, nr 02/05(11).

${ }_{3}^{3}$ Yuri Slezkine pisał o epoce nowoczesnej, szczególnie zaś dwudziestym stuleciu, że było wiekiem Żydów. Żydzi stali się wzorem nowoczesności, ucieleśniając cechy tej epoki: powszechną mobilność, wykształcenie, intelektualne wyrafinowanie, zawodową elastyczność. Dzieje Wrocławia i wrocławskich Żydów w tym czasie mogłyby stać się ilustracją tej tezy. Zob. Y. Slezkine, Wiek Żydów, tłum. S. Kowalski, Warszawa 2006.

${ }^{4}$ M. Halbwachs, Społeczne ramy pamięci, tłum. M. Król, Warszawa 2008; zob. też: B. Koss-Jewsiewicki, Doświadczenie, pamięć, wyobrażenia społeczne, w: Inscenizacje pamięci, red. I. Skórzyńska, Ch. Lavrence, C. Pépin, Poznań 2007. 
przywoływanie przeszłości wiąże się z uobecnieniem wartości, rozpoznawalnych w całej swej różnorodności w symbolicznych przekształceniach miejskiej przestrzeni. Performatywny charakter tej pamięci być może w sposób szczególny ujawnia się $\mathrm{w}$ mieście, $\mathrm{w}$ którym zakorzenienie sensu $\mathrm{w}$ dziejach budzi wątpliwości nie tyle jako przebrzmiały konserwatyzm, ale ze względu na historyczny brak ciągłości między dawnym Breslau i współczesnym Wrocławiem. Te właśnie okoliczności, niemal całkowita wymiana ludności po drugiej wojnie światowej i odrzucenie niemieckiej przeszłości jako obcej w okresie peerelowskiego socjalizmu, sprawiają, że we Wrocławiu od transformacji ustrojowej lat dziewięćdziesiątych „pamiętanie jest pewnym projektem, zadaniem do wykonania" ${ }^{5}$, poszukiwaniem tożsamości miejsca.

Po okresie, w którym funkcję tradycji w tożsamościowej narracji Wrocławia zastąpił czas nowego początku, liczony od końca wojny (z towarzyszącym mu kultem młodości i otwartości), wraz z transformacją nastąpił powrót do przeszłości miasta jako miejsca wspólnego dla różnych zamieszkujących $\mathrm{w}$ nim wspólnot etnicznych czy narodowych ${ }^{6}$. Wpisuje się on w "głębinową falę pamięci, która rozlała się po świecie"7, w odzyskiwanie utraconej, z rozmaitych przyczyn, przeszłości poprzez świadome jej przywoływanie. Etyczny wymiar zwrotu mnemonicznego, który w europejskim kontekście widoczny jest przede wszystkim w stosunku do Holokaustu, dotyczy także krytycznego spojrzenia na sposób traktowania narodowej historii ze względu na zarzucaną mu etniczną stronniczość ${ }^{8}$. Chronić przed nią ma zakorzenienie we wspólnej, wielokulturowej pamięci miejsca, co w przypadku Wrocławia znajduje swoje szczególne uzasadnienie.

Włączenie opowieści o dawnym Breslau we współczesną pamięć miasta jest przekroczeniem zideologizowanej wersji jego dziejów, tworzonej po 1945 roku. Od lat dziewięćdziesiątych niemiecka przeszłość Wrocławia powraca, a zarazem, poddawana procesom muzealizacji i estetyzacji, przekształca się w rodzaj historycznego simulacrum. Procesy te obejmują działania o zróżnicowanym charakterze, których zasięg wydaje się wykraczać poza realizację politycznej strategii miasta. Jednak choć coraz częściej przeszłość Wrocławia funkcjonuje poza ramami wyznaczonymi historią państw

${ }^{5}$ C. Pépin, Wstęp, w: Inscenizacje pamięci, dz. cyt., s.21.

6 Tak można czytać monografię Wrocławia autorstwa Normana Daviesa i Rogera Moorhouse'a o znaczącym tytule: Mikrokosmos. Portret miasta środkowoeuropejskiego, tłum. A. Pawelec, Kraków 2002.

7 P. Nora, Czas pamięci, „Res Publica Nowa” 2001, nr 7.

8 Aleida Assmann zwracała uwagę na skłonność do zamykania narodowej pamięci w kręgu własnych bohaterów i ofiar, co zwykle łączy się z legitymizacją autorytaryzmu (zob. A. Assmann, Między historia a pamięcią. Antologia, red. M. Saryusz-Wolska, Warszawa 2013). 
narodowych, przekształcenie jej w rodzaj symulakrycznej dekoracji oznacza raczej wygaszanie sporu o pamięć niż budowanie dialogu, który otwierałby nowe perspektywy poszukiwania tożsamości miasta. Na tym tle postać Edyty Stein i jej upamiętnienie w rodzinnym mieście może stanowić wyzwanie i szansę. Żydowski dom, poczucie obywatelskiego zobowiązania i odpowiedzialności wobec niemieckiego państwa, filozoficzna droga poszukiwania prawdy, przyjęcie chrześcijaństwa oraz wstąpienie do zakonu karmelitanek, wreszcie będąca ich duchowym dopełnieniem śmierć w Auschwitz splatają się w jej życiu, które „jednoczy w sobie dramatyczną syntezę naszego stulecia" ${ }^{\prime \prime}$ i samo staje się uobecnieniem uniwersalistycznego wymiaru dialogu.

\section{Pamięć i upamiętnienie Edyty Stein}

Zróżnicowane formy upamiętniania Edyty Stein we Wrocławiu łączą poszukiwania lokalnej tożsamości z uniwersalnością przesłania pierwszej wrocławskiej świętej. Wskazują na to same okoliczności powstania towarzystwa jej imienia, które zostało założone w 1989 roku, a zatem dwa lata po beatyfikacji Edyty Stein ${ }^{10}$, i jest organizacją, która odgrywa najistotniejszą rolę $\mathrm{w}$ badaniu i popularyzowaniu jej życia oraz spuścizny w rodzinnym mieście. TES (Towarzystwo im. Edyty Stein) powołano z inicjatywy wspólnoty parafialnej kościoła św. Michała Archanioła, do której niegdyś należała także Edyta Stein, oraz studentów i badaczy wywodzących się ze środowiska uniwersyteckiego.

Rozpoznawanie przestrzeni miasta poprzez odnajdywanie $w$ niej miejsc związanych z Edytą Stein zaowocowało wydaniem przez TES w 2013 roku mapy Wrocław Edyty Stein ${ }^{11}$. Ma ona służyć przede wszystkim upamiętnieniu Edyty Stein, a zarazem przekształca te miejsca w znakowe reprezentacje przeszłości zarówno parafii, jak i całego miasta. Zaznaczone zostały na niej dwa rodzaje miejsc. Pierwsze wiążą się głównie z najwcześniejszym okresem życia, który Edyta Stein spędziła we Wrocławiu. Pozwalają odnaleźć domy, w których mieszkała, szkoły, w których się uczyła, zlokalizować ro-

\footnotetext{
9 Słowa papieża Jana Pawła II wypowiedziane podczas beatyfikacji w dniu 1 maja 1987 w Kolonii www.vatican.va/news_services/liturgy/saints/ns_lit_doc_19981011_edith_stein_ pl.html [dostęp 29.03.2014].

${ }^{10}$ Informacje na temat historii i aktualnej działalności TES można znaleźć na www. edytastein.org.pl.

${ }_{11}$ Do pobrania na www.edytastein.org.pl/pl/4-edyta-stein/1-sladami-edyty-stein [dostęp 29.03.2014].
} 
dzinne przedsiębiorstwo, a także miejsca ważne ze względów religijnych dla rodziny Steinów - obie synagogi, seminarium rabinackie czy cmentarz. Wskazane zostały też miejsca, które pojawiają się w autobiograficznych zapiskach. We wspomnieniach Edyty Stein Wrocław przywoływany jest z nostalgią jako miasto młodzieńczych doświadczeń i fascynacji, a jego obraz przedstawiany bywa w konwencji bliskiej baśniowej opowieści, czego przykładem jest opis Uniwersytetu ${ }^{12}$. Pojawia się w nich również Park Szczytnicki, gdzie spotykała się z uniwersyteckimi przyjaciółmi, a także Ostrów Tumski, „wrocławski Watykan”, odgrodzony od gwaru miasta, urzekający pięknem i przyciągający atmosferą duchowego skupienia ${ }^{13}$. Własna droga duchowa Edyty Stein, która ją kierowała ku pobożności bliskiej atmosferze tej wrocławskiej katolickiej wyspy, wskazana jest na mapie poprzez trzy miejsca: uliczkę prowadzącą od rodzinnego domu do kościoła św. Michała Archanioła (nosi ona dziś imię Edyty Stein ${ }^{14}$ ), tenże kościół oraz dworzec kolejowy (jako swoiste miejsce przejścia w kolejnych podróżach i powrotach, po być może i tę ostatnią drogę siostry Teresy Benedykty od Krzyża - prowadzącą do Auschwitz).

Pierwszy rodzaj miejsc wskazanych na mapie to miejsca-ślady obecności Edyty Stein, a jednocześnie miejsca-relikty przeszłości, które poprzez ich zmysłowo daną bezpośredniość mają umożliwiać szczególny kontakt z minioną rzeczywistością miasta. Przeobrażane w miejsca upamiętniania, muzealizowane, podlegają jednak opisywanemu przez Assmann paradoksowi: „ich konserwacja, której celem jest zachowanie autentyzmu, nieuchronnie

12 ,Stary, szary budynek nad Odrą stał mi się wkrótce ukochany i bliski. W wolnych chwilach, znalazłszy pustą salę wykładową, lubiłam siedzieć na jednej z szerokich desek okiennych, wypełniających głębokie nisze w murze, i tam pracowałam. Z tej wysokości mogłam patrzeć na rzekę i most uniwersytecki, na którym wrzało życie, i miałam wrażenie, że jestem księżniczką na zamku. Podobnie swojsko czułam się w przyległym, równie czcigodnym konwikcie, gdzie odbywaliśmy psychologiczne i filozoficzne seminaria, a także w bibliotece uniwersyteckiej, dawnej fundacji kanonickiej przy Sandstrasse (obecnie ul. Św. Jadwigi)”, cyt. za: M. Łagiewski, Wrocławskie lata Edyty Stein (1891 - 1913), w: E. Stein, Dzieje pewnej rodziny, tłum. J.I. Adamska OCD, Wrocław 1991, s. 13.

13 „Czułam się tu jakby w świecie ciszy i spokoju, przeniesiona w dawno minione stulecia" - pisała. Ten estetyzujący przeszłość sposób patrzenia nie przesłaniał jej poszanowania innej niż własna duchowości, na co wskazuje dalsza część tego cytatu: „Lecz do wnętrza tych pięknych kościołów nie wchodziłam, przede wszystkim dlatego, że odbywały się tam właśnie nabożeństwa. Nie miałam tam nic do szukania i uważałam, że postąpię taktowniej, gdy innym nie zakłócę pobożności". E. Stein, Światłość w ciemności. Wybór pism, t. I, Autobiografia, tłum. J.I. Adamska OCD, Kraków 1977, s. 93-94.

14 Ta inicjatywa TES wpisała się w potransformacyjną falę zmian nazw wrocławskich ulic, podczas której „uczczono też pamięć kilku słynnych niemieckich wrocławian, między innymi noblistę Maksa Borna i niedawno beatyfikowaną Edith Stein". G. Thum, Obce miasto. Wroctaw 1945 i potem, tłum. M. Słubicka, Wrocław 2005, s. 425. 
prowadzi do jego utraty"15. Odrestaurowany dom Edyty Stein, który obecnie jest siedzibą TES, wyposażony w odzyskane rodzinne meble, wpisuje się w ów proces zachowania miejsca, którego ceną jest utrata statusu śladureliktu przeszłości i przekształcenie $\mathrm{w}$ wymagający interpretacji znak.

Drugi rodzaj miejsc zaznaczonych na mapie i określanych $\mathrm{w}$ legendzie jako "Miejsca pamięci o Edycie Stein” wiąże się z kultem pierwszej wrocławskiej świętej. Zapewne winien on obejmować ich zdecydowanie więcej, uwzględniać wizerunki siostry Teresy Benedykty od Krzyża, które pojawiły się licznie we wrocławskich kościołach po jej kanonizacji. Natomiast mapa prezentuje te wśród nich, które wydają się odpowiadać także kategorii "miejsc pamięci" w rozumieniu francuskiego historyka Pierre'a Nory, a zatem symbolicznego uobecnienia Edyty Stein w przestrzeni miasta. Taki charakter ma przede wszystkim Europejski Krzyż Pokoju, Dom Edyty Stein (gdy tym mianem nie będziemy określać samego budynku), kościół (którego reprezentacją jest neogotycki kościół parafialny p.w. Archanioła Michała), droga (w obu wyróżnionych już wyżej postaciach: ulicy wiodącej do kościoła i torów prowadzących do Auschwitz). Pozostałe wskazane na mapie miejsca trudno jednak uznać za symboliczne uobecnienia. Są to mniej czy bardziej udane artystycznie przedstawienia (od mozaiki, przez rzeźbę, po wizerunek na kielichu mszalnym) oraz pomniki świadczące o kulcie św. Teresy Benedykty od Krzyża we Wrocławiu (niekiedy upamiętniające też ważne wydarzenia w życiu Kościoła, jak 46 Kongres Eucharystyczny, podczas którego odwoływano się do jej duchowej drogi). Są wśród nich także pomnikowe reprezentacje - dowody uznania Edyty Stein za znaczącą postać dla dziejów miasta (ich przykładem jest jej popiersie w Galerii Sławnych Wrocławian w Ratuszu).

Mapa Wroctaw Edyty Stein jest kolejną publikacją (po przewodniku pod tym samym tytułem ${ }^{16}$ ), która mieści się we współczesnym modelu zwiedzania, łączącym trasy pielgrzymkowe i turystyczne $\mathrm{z}$ rozbudowanymi opisami o charakterze historycznym (w tym także z zakresu wiedzy o sztuce), jakich wiele odnajdziemy na całym świecie. Doświadczenie świętości w miejskiej przestrzeni jest $\mathrm{w}$ tym modelu zwiedzania zapośredniczane (jeśli nie wręcz zastępowane) przez edukacyjne i turystyczne praktyki, dziś wyraźnie zorientowane na tworzenie rozbudowanych spektakli i wizualną ilustracyjność (na marginesie warto zauważyć, że choć nie wydają się one wynalazkiem naszych czasów - zwłaszcza gdy przywołać imaginarium religijne doby

${ }^{15}$ A. Assmann, dz. cyt., s. 176.

${ }^{16}$ D. Mrozowska, H. Sokólska, Wrocław Edyty Stein. Przewodnik ilustrowany, Wrocław 1997 (wyd. II: Wrocław 2006). 
baroku - to nowy jest sposób ich funkcjonowania: estetyzacja, która nie wymaga odniesienia do sacrum).

\section{Uobecnienie świętości w przestrzeni miasta}

Troska o pamięć może prowadzić do muzealizacji czy estetyzacji przeszłości, do jej rozmaitego wykorzystywania (od ideologii po turystykę) i tak dzieje się dziś najczęściej. Zdecydowanie rzadziej daje szansę na odkrywanie uobecniającego się w przeszłości sensu. Poszukiwanie tak rozumianego symbolicznego wymiaru miejsca stawia nas przed innym paradoksem niż wspomniana wyżej antytetyczność dążenia do zachowania autentyczności miejsca i jej utraty przez przekształcenie w znakowy nośnik pamięci. Powrócić bowiem trzeba do pytania o charakter obecności świętych we współczesnej miejskiej przestrzeni i ich rolę w kształtowaniu tożsamości miasta. Anna Grzegorczyk poprzez postać Edyty Stein wskazywała na dylemat, jaki się z tym wiąże, odsyłając do lektury biblijnego tekstu i do przeciwstawienia toposu pustyni - toposowi miasta. W perspektywie mistycznego doświadczenia (które, jak wiemy, stało się udziałem siostry Teresy Benedykty od Krzyża) święci:

Paradoksalnie wpisują się w kulturę miasta; paradoksalnie, bo po to, by nimi zostać, musieli je opuścić. Co więcej, to w opuszczonym symbolicznie mieście doznają wyniesienia na ołtarze, pomnikowej czci i wszelkich innych przejawów kultu włączających ich w kulturę miasta i tym samym dziedzictwo kulturowe ${ }^{17}$.

Ta paradoksalność, jak przypomniałby Mircea Eliade, należy do natury hierofanii, ujawnia właściwą przejawianiu się sacrum ambiwalencję aksjotyczną, skoro sacrum zawsze objawia się w tym, co od niego różne ${ }^{18}$. Wrocław nie był w czasach Edyty Stein - i nie jest też współcześnie - Niebiańską Jerozolimą, lecz przestrzenią profanum, w której uobecnienie świętości łączy się z przekształceniem świeckiej przestrzeni. Nie jest to wszak transformacja radykalna, prowadząca do zniesienia odrębności sacrum i profanum, do przebóstwienia, które staje się udziałem świętych jako tych, którzy są przewodnikami na drodze do zbawienia świata ${ }^{19}$. Poza właściwym światu hierofa-

17 A. Grzegorczyk, Obecność wartości, Poznań, 2010, s. 99.

18 M. Eliade, Traktat o historii religii, tłum. J. Wierusz-Kowalski, Warszawa 1966.

19 „Bóg pragnie przez tych, do których sam mówi na szczycie góry, przemówić do stojących u jej podnóża". E. Stein, Z własnej głębi. Pisma różne, łłum. J.I. Adamska OCD, Kraków 1978, s. 195. 
nicznym napięciem, którego postacią jest przeciwstawienie toposów pustyni i miasta (to ostatnie "nie stanowi właściwego miejsca kontaktu z Transcendencją"20), współczesne miasto - i to właśnie chce podkreślić Grzegorczyk nie sprzyja przejawianiu się świętości.

Dziś miasto $\mathrm{w}$ mniejszym stopniu niż duchowy krajobraz wydaje się stanowić symulakryczną przestrzeń wypełnioną pozbawionymi znaczenia formami, w której rytuały zostały zastąpione przez widowiska. Postacie świętych pojawiają się w nim najczęściej jako rodzaj dekoracyjnego tła historycznej narracji o przeszłości, a zmuzealizowany charakter ich upamiętniania dominuje nad symbolicznym uobecnieniem, jakie wiąże się z miejscami pamięci. Miejsca pamięci, w odróżnieniu od form upamiętnienia, odwzorowują bowiem strukturę doświadczenia wartości, wobec którego ich wizualizacja zawsze okazuje się czymś wtórnym. We Wrocławiu miejsca pamięci w tym rozumieniu stanowią bez wątpienia Dom Edyty Stein i Europejski Krzyż Pokoju.

Zacznijmy od Domu, który wiąże się z zakorzenieniem. Jak wiemy, dla Edyty Stein judaizm był bardziej częścią stylu życia rodziny, fundamentem zaangażowania religijnego jej matki, niż własnym duchowym doświadczeniem. W jakim znaczeniu i wymiarze stanowił o jej przynależności do narodu przymierza ${ }^{21} \mathrm{w}$ mieście, które było przecież jednym $\mathrm{z}$ głównych ośrodków haskali, ruchu kulturowego otwarcia Żydów na świat - to pytanie nie wydaje się rozstrzygnięte w świetle wspomnień i relacji samej Edyty Stein. A zarazem nie sposób przecenić wagi tegoż pytania w perspektywie rozważań nad uniwersalnym wymiarem ofiary św. Teresy Benedykty od Krzyża, męczeńskiej śmierci karmelitanki w habicie z żółtą gwiazdą Dawida22. Jak już wspomniano, wrocławski dom rodzinny Steinów łączył zakorzenienie i otwartość w sposób charakterystyczny dla swojej epoki, co zapewne składa się także na zrozumienie fenomenu Edyty Stein. Natomiast transformacja symboliczna jej domu jako miejsca wyróżnionego w miejskiej przestrzeni nie wydaje się związana z intelektualnym klimatem tamtego czasu czy atmosferą miejsca ważnego w biografii świętej. Dziś to Dom Patronki Europy, co

20 A. Grzegorczyk, dz. cyt., s. 98. Można na marginesie zauważyć, że choć zapewne i dziś miasto nie jest miejscem, które sprzyja kontaktowi z Transcendencją, to wydaje się bardziej niż kiedykolwiek odpowiednikiem pustyni, która dla anachoretów była wszak mniej odosobnieniem sprzyjającym kontemplacji, co wyzwaniem i próbą, której analogią może być błądzenie po ulicach miasta.

21 „Narodem czyni Izrael dopiero przymierze” - pisał A.M. Goldberg (Tenże, Judaizm, w: Pięć wielkich religii świata, tłum. J. Doktór, Warszawa 1986, s. 90-91).

22 Dla Normana Davisa życie i śmierć Edyty Stein było „najlepszą chyba ilustracją meandrów religijnych w międzywojennych Niemczech” (N. Davies, R. Moorhouse, dz. cyt., s. 383). 
czyni zeń przestrzeń międzykulturowego dialogu i pojednania. Są to także cele Towarzystwa im. Edyty Stein, mającego swoją siedzibę w tym budynku. Liczne dyskusje, spotkania, działania artystyczne, obejmujące swym zasięgiem zróżnicowane pokoleniowo i narodowo środowiska, aktualizują ideę żywej wymiany, współpracy i porozumienia. Symboliczne uobecnienie przybiera postać zadomowienia $\mathrm{w}$ przestrzeni tak właśnie rozumianej otwartości i poczucia etycznej odpowiedzialności. Dla przykładu wskażmy na jeden $\mathrm{z}$ realizowanych ostatnio we współpracy z fundacją Dom Pokoju projektów „Religia - Kultura - Edukacja”. To cykl spotkań poświęconych przedwojennym wrocławskim teologom: Edycie Stein, Dietrichowi Bonhoefferowi, Benno Jacobowi i Katherinie Staritz. Choć wywodzą się oni z różnych tradycji religijnych (od katolicyzmu, przez luteranizm po judaizm), tym, co ich łączy:

Jest otwartość na kulturę, społeczeństwo, a przede wszystkim odważna postawa $\mathrm{w}$ walce $\mathrm{z}$ nazizmem i antysemityzmem. $\mathrm{Z}$ tego powodu jako mieszkańcy Wrocławia i Dolnego Śląska powinniśmy zachowywać o nich szczególną pamięć wyrażaną nie tylko poprzez fundowanie pomników, nazywanie ich nazwiskami ulic lub placów, ale także pamięć poprzez czytanie tekstów oraz rozmyślanie nad ich sensem, zwłaszcza w odniesieniu do współczesności²3.

Ten postulat wpisuje pamięć $\mathrm{w}$ troskę o duchowy krajobraz miasta, by mimo istniejących form upamiętniania ważnych $\mathrm{w}$ jego dziejach postaci, nie było ono przestrzenią symbolicznie opustoszałą, by ich śladom towarzyszyła podtrzymująca ich obecność transformacja doświadczenia.

Przejście od wrocławskiego domu Edyty Stein przy ul. Nowowiejskiej 38 do Europejskiego Krzyża Pokoju zajmuje nie więcej niż 10 minut. Ale w wymiarze symbolicznym to cała droga życia siostry Teresy Benedykty od Krzyża, jej ziemski początek i kres. Droga, na której chrzest i wstąpienie do zakonu stanowią duchowy przełom.

Przydomek "od Krzyża” wskazuje w zakonie na powołanie i gotowość życia w duchu określonych tajemnic wiary. Dla Edyty był to również symbol krzyża nałożonego na naród żydowski, a jak się miało wkrótce okazać jej własnego krzyża 24

To droga chrześcijaństwa, inna niż judaizmu, a tę odrębność skupia i wydobywa właśnie Krzyż - odmienna niż w kulturze i religii żydowskiej waloryzacja ofiary i cierpienia (co boleśnie uświadamiały nieporozumienia

${ }^{23}$ Więcej na stronie współpracującej z TES Fundacji Dom Pokoju: www.dompokoju.org.

${ }^{24}$ D. Mrozowska, W Karmelu (1933-1942), w: E. Stein, Dzieje pewnej rodziny, dz. cyt., s. 35. 
wokół oświęcimskiego Karmelu oraz krzyża na oświęcimskim żwirowi$\mathrm{sku})^{25}$.

Wrocławski pomnik Europejski Krzyż Pokoju (rys. 1), wykonany przez austriackiego artystę Helmuta Strobla, ma kształt krzyża, a zarazem są to jak pisała Grzegorczyk - ,jakby dwie tablice Mojżeszowe - Stary i Nowy Testament". Tak zinterpretować można złożoną formę krzyża, w którym:

Odróżnia się dwie części (drewnianą i metalową) i zarazem je łączy; spoiwem rzeźbiarskim jest sedila, symbolicznym słowa Chrystusa zapisane w języku hebrajskim: Ojcze w ręce Twoje oddaje ducha mego [Ps 31], judaizm i chrześcijaństwo, mimo różnic, zostają zjednoczone; w części chrześcijańskiej - drewnianej tkwi 365 gwoździ, w części judaistycznej została zamieszczona inskrypcja odnosząca się do osoby tego samego Boga ${ }^{26}$.

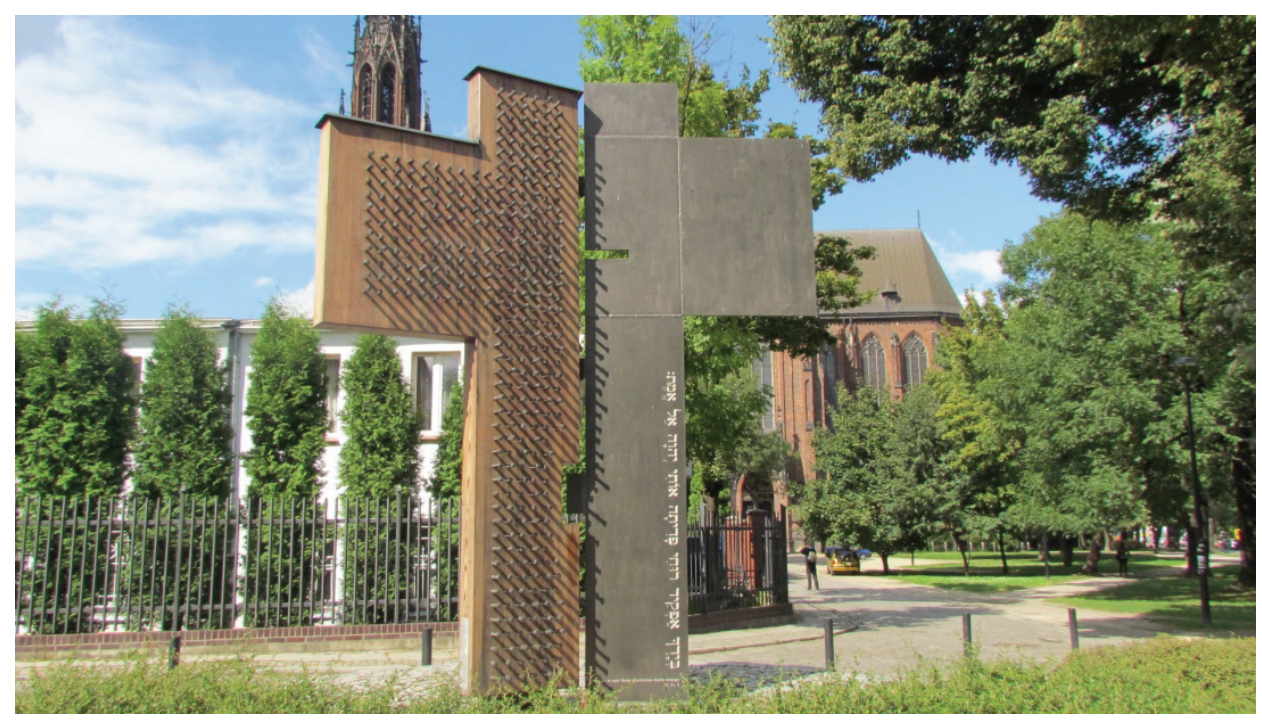

Rys 1. Wrocław: Europejski Krzyż Pokoju (fot. P.J. Fereński)

${ }^{25}$ Pokazuje je także nadużycie interpretacyjne, które pojawiło się na stronie internetowej wrocławskiej parafii św. Michała Archanioła, dotyczące Europejskiego Krzyża Pokoju. Napisano tam, że 365 gwoździ, tyle, ile jest dni w roku, „symbolizuje cierpienie, jakie codziennie dotyka ludzi", co w zestawieniu z niemieckim tytułem projektu Europa Friedenkreutz - geweiht der Europa friedensheiligen Edith Stein. 365 Gedenk-Minuten uznać wypada za rezultat odczytania, które jest skoncentrowane wokół antropologicznego wymiaru cierpienia Chrystusa. Za: www.wroclawm.salezjanie.pl/index.php?d=ciekawe/Krzyzp/KrzyzPokoju0 [dostęp: 31.03.2014].

${ }^{26}$ A. Grzegorczyk, dz. cyt., s. 114. 
Pomnik poświęcony jest świętej, w której życiu dokonało się szczególne zespolenie judaizmu z chrześcijaństwem bez zawłaszczenia tożsamości żadnej z tych religii, na co intencjonalnie wydaje się wskazywać jego artystyczny kształt - zestawienie ciepła drewnianej części krzyża z gładką szarością metalu niczym z wypolerowanym kamieniem - i ewokowany przez nie ciąg skojarzeń: Chrystusowy krzyż i kamienne tablice Przykazań, drewniane krzyże nagrobków chrześcijańskich i żydowskie macewy... Pielgrzymka Helmuta Strobla z pierwowzorem pomnika do siedmiu miast związanych z Edytą Stein - Kolonii, Echt, Berlina, Drezna, Wrocławia, Oświęcimia i Insbrucka - była religijnym wyrazem intencji artysty. Współbrzmiały z nimi życzenia, jakie napłynęły z Watykanu na uroczystość poświecenia pomnika we wrześniu 2008 roku: „by Krzyż Pokoju wzniesiony we Wrocławiu był dla obecnych i przyszłych pokoleń znakiem miłości przebaczającej i pojednania" 27 . Jednak by ten udany artystycznie pomnik nie posłużył temu, co zyskało już miano kiczu pojednania, deklaracji przysłaniającej różnice i niepozwalającej na pracę pamięci, warto przypomnieć słowa wiersza Anny Kamieńskiej poświęconego Edycie Stein: „Szła w niebo ogromna i prosta / Jak słup dymu z ofiary Abla"28. Trzeba zatem widzieć różnicę w sposobie pojmowania ofiary i religijnej waloryzacji cierpienia, która nie przesłoni możliwości ich zespolenia w doświadczeniu św. Teresy Benedykty od Krzyża. Doświadczenia, które jest wiedzą krzyża w podwójnym znaczeniu: jako teologii krzyża i jako szkoły krzyża. Jej wrocławski pomnik - Europejski Krzyż Pokoju - tworzy część duchowego krajobrazu miasta, niezależnie od sporów, które wciąż budzi postać Patronki Europy między chrześcijańskimi a żydowskimi środowiskami.

W tej perspektywie Wrocław, określany hasłem: miasto spotkań, może przekroczyć historyczną wizję wielokulturowości, do której wciąż się odwołujemy, mimo że wizja ta należy do minionej przeszłości, i skierować się ku tworzeniu przestrzeni dialogu. Dialogu, który nie jest łatwą drogą, gdyż jego ceną nie może być ani utrata tożsamości własnej, ani zawłaszczenie tożsamości Drugiego. Dialogu, o którym Emmanuel Lévinas pisał, że „Nie doprowadza do jakiegoś wniosku, ale stanowi jakby samo życie prawdy. Dialog żyje samym swym otwarciem, obecnością rozmówcy"29. Obecność Edyty Stein w duchowym krajobrazie Wrocławia oznacza gotowość do tak właśnie rozumianej otwartości ${ }^{30}$.

27 "Gość Niedzielny" 12.10.2008, s. 3.

28 A. Kamieńska, Doktor Edyta Stein (z tomu: Dwie ciemności i wiersze ostatnie, Poznań 1989).

${ }^{29}$ E. Lévinas, Trudna wolność. Eseje o judaizmie, tłum. A. Kuryś, Gdynia 1991, s. 171.

${ }^{30}$ Jej ilustracją może być projekt zgłoszony do realizacji w roku 2016, gdy Wrocław będzie Europejską Stolicą Kultury: Gwiazda Zbawienia. Wrocław - Breslau, dialog wobec Zagłady. 


\section{Edith Stein in the Memory of the City of Wrocław}

\section{Summary}

The article seeks to explore the role of Edith Stein's memory in creating the contemporary identity of the city of Wrocław. The author distinguishes between two forms of this memory, that is to say remembrance and symbolic places (lieux de mémoire). The places of remembrance of Edith Stein, who was born in Breslau, are connected with her biography and the time she spend in this city. The symbolic places of the memory of Edith Stein represent the values of her life (such as the European Peace Cross, meticulously analysed by the author). Both forms of memory variously transformed the space of the city in significant landscape.

Edyta Stein jest w nim "figurą losu Żydów z Breslau”, a zarazem figurą tragicznej kondycji człowieka w wieku totalitaryzmu, "filozofką niemiecką, katolicką teolożką i mistyczką" (cyt. za maszynopisem projektu). 